\title{
Distributive Politics and Manipulative Policy in Local Election
}

\author{
Dedy Hermawan Universitas Lampung, Indonesia \\ Robi Cahyadi Kurniawan Universitas Lampung, Indonesia
}

\begin{abstract}
Distributive politics is part of the concept of patronage or clientelism, term of clientelism commonly referred to in some scientific literature. Research on distributive politics in the context of local politics, especially in the election of regional heads is still rare. Previous studies are still conducted within the national scope, such as presidential and legislative elections. This research tries to answer the question of how the process of distributive politics and manipulative policies runs in the local context of Bandar Lampung Local Election in 2015. The study was conducted in Bandar Lampung City in September 2016 until January 2017. This research used qualitative method through in-depth interview approach to informants related to the research. The informant consisted of several political actors, Herman HN's successful team and academics. The result of this research indicates that politics of distributive among voters occurs in the selection of Bandar Lampung Mayor. There is a symbiotic mutualism between candidate and the voters in Bandar Lampung Local Election. Voters can be influenced by the choice of imaging of candidate, through the concept of distributive politics or pork barrels politics or provide necessary needs for the voting community with infrastructure policy; roads and bridges, free education, free health and religious social assistance. Other results indicate that the manipulative policies carried out by candidate make voters lulled to absurd performance that ends in the Bandar Lampung City budget crisis after the policy is rolled out.
\end{abstract}

\section{Keywords}

Distributive Politics; Manipulative Policy; Bandar Lampung Local Election

\section{INTRODUCTION}

Clientelism is a personalistic power relation (Hutchcroft, 2014), and material benefits are exchanged with political support. Hutchcroft, referring to previous writings, especially Scott (1972),

Dedy Hermawan is a lecturer at Department of Government Science, Universitas Lampung. His research foci on: Beureucratic Reform, Public Services, Governance and Empowerement. Email: dedy.hermawan@fisip.unila.ac.id.

Robi Cahyadi Kurniawan is a lecturer at Department of Government Science, Universitas Lampung. His research foci: Democracy and electoral, Clientelism and money politics. Email: robi.cahyadi@fisip.unila.ac.id. emphasizes that clientelistic relations are face-to-face relationships.

One of the most basic definitions of clientelism, comes from Lemarchand. Lemarchand (1972), defines political clientelism as a more personal, affective and reciprocal relationship between actors, or some actors, based on unequal sources and involving mutually beneficial transactions and political consequences. Based on this definition there are four 
points that can be analyzed. First, assistance received by the client. clientelism is a personal and personalistic Eisenstadt and Roniger (1984) suggest relationship that supersedes or that the application of a reciprocal supplements formal and abstract social paradigm for clientelism, in practice there relationships with a bond based on is an imbalance in patron-client acquaintance, friendship and shared relationships. Roniger (1994) adds this to interest or emotional interest in the system of redistribution of powers, common. The choice to use this type of inherent in this kind of social relations. interpersonal relationship has been Redistribution according to Sahlins described in several ways by (1972) is a distinct form of reciprocity in anthropologists. Some individuals in which unequal position of power dictates clientelism dominate friendly relations, rules, which move from the center (where others see the tension between trust and authority lies) and then distributed solidarity and unequal power relations, downward in different forms.

different approaches perceive personal Third, limited resources distributed interaction as an instrument for the through patronage. Some anthropological attainment of collective goals and identity (Silverman 1965; Scott 1977; Waterbury 1977). approaches have sought to apply alternative theoretical models to investigate the social and political

Second, concerning mutual relations. Scott (1977) identifies interaction as functions of resource scarcity, as well as its cognitive dimension. One of them is reciprocal according to the perceived benefits of clientelistic practice. This relationship is not easily measured on the same scale of what the patron gives to the client, or what the client provides (support, protection and alliances). The variety of goods exchanged in the clientel relationship is so broad and specific, it makes the framework of reciprocity weak and blurred. A balanced balance is likely the idea of moral economy, developed following the work of Edward Thompson (1971) and James Scott's (1976) research on peasant resistance in Indonesia. The condition of scarcity and economic inequality, understood as ethical and desirable to maintain subsystem level, even if they bring about economic change (Geertz, 1970). In the same way, clientelism has often been to be influenced by the level and type of described as a moral tendency to 
maximize the unfair relations of personal (incumbent) win absolute compared to power (Torsello, 2012).

Vice Mayor; Thobroni Harun and

Other concepts of patronage or independent candidate. According to the clientelism are pork barrel projects, also researcher's initial assumption there is known as distributive politics (Evans, practice political distributive that occurred 2004). The distribution politics or pork in Bandar Lampung Local election 2015 barrel is defined as a form of distributing that caused Herman HN won and other material aid usually in the form of candidates lost in election. This study contracts, grants, public works projects from elected officials to the electoral districts (Schaffer, 2007). The distribution politics or pork barrel relates to public tried to find answers about distributive politics on Bandar Lampung Local election 2015, especially on the incumbent candidate.

works projects (Lancaster \& Patterson, 1990) such as road improvement projects, improvements to river facilities and port improvements (Ferejohn, 1974). These public facilities improvement projects are often used as classic examples of pork barrels cited in many literature on the study of distribution politics or pork barrels (Weingast, Shepsle and Johnsen, 1981; Yiannakis, 1982; Lancaster \& Patterson, 1990; Evans, 2004). The distribution politics or pork barrel not only covers physical projects such as public facilities improvement, but also in other forms such as in the form of welfare distribution (Magaloni, 2006; Stokes, 2007b).

Bandar Lampung local election in December 2015 is interesting to investigate further, because Herman HN

\section{RESEARCH METHOD}

Some experts define qualitative research as follows; according to Patton (2006) a naturalistic qualitative design that studies the occurrence of activities and processes naturally which means they are not planned or manipulated, qualitative methods are generally oriented in terms of exploration, disclosure, and inductive logic, the inductive design begins with the observation specific and build towards a general pattern, the analytical dimension arises from openended observations.

Qualitative researchers begin by defining very general concepts, changing concepts as a product or result, qualitative observations are made through wide lenses, looking for patterns between 
relationships between previously politics or pork barrels (Weingast, Shepsle unspecified concepts, data collection in \& Johnsen, 1981; Yiannakis, 1982; qualitative traditions researchers should Lancaster \& Patterson, 1990; Evans, use themselves as an instrument 2004). The distribution politics or pork following the assumptions of cultural barrel not only covers physical projects assumptions as well as following the data such as public facilities improvement, but and the researcher is expected to be flexible and reflective but still distance, consequently qualitative research is a participatory observation or observation involved (Brannen, 2005).

\section{RESULT AND DISCUSSION}

\section{Distributive Politics}

Other concepts of patronage or clientelism are pork barrel projects, also known as distributive politics (Evans, 2004). The distribution politics or pork barrel is defined as a form of distributing material aid usually in the form of contracts, grants, public works projects from elected officials to the electoral districts (Schaffer, 2007). The distribution politics or pork barrel relates to public works projects (Lancaster \& Patterson, 1990) such as road improvement projects, improvements to river facilities and port improvements (Ferejohn, 1974). These public facilities improvement projects are often used as classic examples of pork barrels cited in many literatures on the study of distribution also in other forms such as in the form of welfare distribution (Magaloni, 2006; Stokes, 2007b).

High cost politics conducted by Herman HN, the activity was categorized as pork barrel politics or pork barrel politic. Free health activities and programs, free education, infrastructure development is all done to make people happy and correlate with their choice of pilot project in Bandar Lampung 2015. Many voters, especially in Bandar Lampung who do not understand and know that the practices of program activities that funds Bandar Lampung city budget is categorized as part of pork barrel politics. The political practice of pork barrels in Bandar Lampung supports the existing theory of patronage theory about pork barrel politic.

Pork barrel politics is also often referred to as distribution (distributive politics) can be defined as a form of distribution of material assistance (often in the form of contracts, grants, or public works projects) to the district/city of 
elected officials. In general, it can be said that pork barrel is associated with public works projects such as road repair projects, improvements to facilities around the river, and port improvements. Public facilities improvement projects are often used as classic examples of pork barrels cited in many pork barrel political literature reviews. This does not mean that pork barrels cover only physical projects in the form of public facilities improvements, but pork barrels can also take the form of welfare distribution (Stokes, 2013).

The political practice of pork barrels or distributive politics or more commonly known as pork barrel politics in Bandar Lampung is one example that not always the electorate community in urban areas with higher education and relatively better welfare than rural people are able to sort and choose programs and policies with right. The policy of making flyovers as an example, this policy does not solve traffic congestion but only limited to lighthouse projects that spend funds by way of indebtedness. This debt will affect the balance sheet of the City Government of Bandar Lampung, if the debt is not resolved during the Herman HN leadership, it will become the burden and responsibility of the next mayor.

\section{Manipulative Policy}

The absolute victory of the Herman HN and Yusuf Kohar couples was attributed to several developments that Herman HN had done in the previous leadership period, in pairs with Deputy Mayor Thobroni Harun. In addition, the background of Yusuf Kohar as a businessman helped in terms of bonding and also relationships with colleagues of other entrepreneurs and workers in the city of Bandar Lampung. Yusuf Kohar who previously served as Vice Chairman of the Democratic Party of Lampung Province also received full support from M. Ridho Ficardo who served as Chairman of the Democratic Party of Lampung Province who also occupied the position of Lampung Province Governor.

Development has been done by the Mayor Herman $\mathrm{HN}$ in previous periods such as the development of road infrastructure and fly over, free health, free education has been done since Herman HN served as Mayor elected at the elections Bandar Lampung city in 2010 (Field observation data).

Networks and relations in the political world are recognized by this couple as one of the decisive factors for their victory, with a structured and long-established network formation pattern since 1999 
precisely after the 1998 reform. Patterns by training and education for employees and workers, direct employees in various companies, factories and warehouses so that intertwined face to face communication in the campaign process.

Mayor of Bandar Lampung, Herman HN has its own network outside the network of winning partner M. Yusuf Kohar. The winning team reported to the Bandar Lampung City KPU who served as Leason Officer (LO) consisted of three persons, Rahmat Husein DC, Resada Khadafi and Aryanto Yusuf. All three are people directly elected by Herman HN without the involvement of $M$. Yusuf Kohar as his partner to decide, M. Yusuf Kohar only knows and agrees only. The tasks of this team of three are in particular the thinking team and the drafting team covering the whole from the content of the speeches, the preparation of campaign materials and the affairs of the approach to the constituents even to legal assistance in the case of alleged reports in the elections. The three teams also have the authority and freedom to move in the field of implementation in the field up to the evaluation of activities. The three teams coordinate directly with Herman $\mathrm{HN}$ and have their respective duties and job specifications.

\section{High Cost Politics}

The victory of Herman HN paired with Yusuf Kohar in Pilotot Bandar Lampung 2015 is more due to the beautiful strategy played by Herman HN as the Mayor's petahana. The influence of Herman HN on the voting community in Bandar Lampung City is very strong and binding. Since the first era of Herman HN leadership in 2010 and then, while still in pairs with Vice Mayor Thobroni Aaron various breakthrough development of Bandar Lampung city intensively conducted.

Development carried out by Herman HN in the era of 2010 until the year 2014 before Pilwakot Bandar Lampung 2015 implemented massive and favored voters. Infrastructure development became the mainstay of Herman HN, almost all roads that become the authority of the City Government of Bandar Lampung used as hotmix asphalt, including the streets of small alleys. Infrastructure development also extends to the construction of bridges and the most phenomenal is the construction of flyovers in the city (fly over).

Development is also done by providing health insurance for free, especially for the poor. This health insurance is not incorporated in BPJS or 
Table 1. Revenue Original Region of Bandar Lampung City 2010-2015

\begin{tabular}{|c|l|l|l|}
\hline Year & \multicolumn{1}{|c|}{ PAD } & \multicolumn{1}{c|}{$\%$ increase } & \multicolumn{1}{c|}{ Information } \\
\hline 2010 & Rp. 86 billion & & Early lead \\
\hline 2011 & Rp. 162 billion & $88.4 \%$ & \\
\hline 2012 & Rp. 272 billion & $67.9 \%$ & \\
\hline 2013 & Rp. 360 billion & $32.4 \%$ & \\
\hline 2014 & Rp. 425 billion & $18 \%$ & \\
\hline 2015 & Rp. 397 billion & $-6,5 \%$ (minus) & $\begin{array}{l}\text { Not reaching target (target Rp 769 } \\
\text { billion) }\end{array}$ \\
\hline
\end{tabular}

Source: Data processed, Radar Lampung, Wednesday 17 February 2016: A1, and Tribune Lampung, July 25, 2016: 1.

health insurance provided by the central government through Jokowi Health Card, but health insurance provided by Herman HN own funds from the city budget Bandar Lampung. This program is called Regional Health Insurance (Jamkesda) in the form of a healthy card given to all people of Bandar Lampung City by not looking at the socio-economic level of the community. Herman HN health cards may be used by people with middle and upper economic levels, although more priority to the urban poor.

Development priorities focused on three areas, infrastructure, health and education has eroded the city of Bandar Lampung APBD to the point nadirnya. Poor budget management and poor management of health and education benefits have triggered the use of high and uncontrolled budgets. The effect of APBD is to bear too much of the budget burden, with the least income from local revenue (PAD), then the burden of debt becomes increased. This condition causes the Bandar Lampung Municipal Government to suffer budget deficit.

The development undertaken by Herman $\mathrm{HN}$, in addition to infrastructure, health, education also in the form of social assistance for the voters. Construction of inner-city flyovers which is a mainstay program Herman $\mathrm{HN}$ indeed beautify the face of the city but eroded the budget of one hundred twenty five billion dollars owed. Social assistance for the community in the form of compensation for death, religious donation, donation for the wedding using Bandar Lampung municipal budget. In addition to these contributions, the city government's finansial burden is also eroded by the number of honorary and volunteer workers (TKS) paid by funds, the 
honorary staffs are from Herman $H N^{\prime}$ 's $H N$ to maintain quantity of political success team and sympathizers during support of voter society in Bandar the implementation of Bandar Lampung Lampung City can be divided into four 2015 local election.

Social assistance provided by Herman $\mathrm{HN}$ has been done since the first period of leadership from 2010 to 2015 before Pilwakot. The purpose of social assistance is to maintain the pockets of Herman HN vote ahead of the election of regional heads, especially the election of the governor of Lampung in 2014 and the selection of mayor of Bandar Lampung 2015. Assistance carried out continuously rely on social assistance funds in the APBD Kota Bandar Lampung.

Herman HN's concern for the voting community by providing a variety of social assistance in the form of compensation for death, mourning, assistance to the mosque and religious activities up to the help of people who have a celebration of marriage or circumcision by sending paper or drinking water flowers and also sometimes attend wedding party or circumcision. All the help and attention that closely ties the community's choice to Herman HN especially when Pilwakot takes place in 2015.

\section{CONCLUSION}

Pattern of clientelism used by Herman types, that is bymain program in accordance with promise of his campaign well in period of beginning of office year 2010 up to moment win Bandar Lampung 2015 local election. Four types of patterns used include the construction of infrastructure, especially roads and road laying in the city (fly over), providing health insurance area in the form of health cards; outside BPJS and KIS Jokowi, providing free education for elementary, junior high school through environmental development program and social and religious aid.

Herman HN's strength is also on the solidity of his supporters who are mobilized by a working team consisting of Rahmat Husein, Resmen Khadafi and Aryanto Yusuf. In addition, the influence of Rahmat Hidayat's teachings also has a significant impact on women voters and can also serve as a potential voting field in maintaining victory in the Mayor of Bandar Lampung 2015 Election.

Herman $H N$ incumbent victory in Bandar Lampung 2015 Pilwakot an easy victory when seen from its investments since taking office since 2010. The victory Herman HN successful these 
political imagery in the community, Herman victory due to the performance shown during his tenure as mayor is considered successful, so community believe and choose again. Herman's victory also caused his position when he was head of the region, resulting in a popular populist pro-people policy. Herman popularity factor is also huge, so if he had advanced from any independent paths, Herman HN can still win.

\section{REFERENCES}

Anderson, Benedict R.OG. (2000). Kuasa Kata, Jelajah Budaya-Budaya Politik di Indonesia. Terjemahan Revianto Budi Santosa. Yogyakarta: Mata Bangsa.

Agustino, Leo. (2014). Politik Lokal dan Otonomi Daerah. Bandung: Alfabeta Aspinall, Edward \& Sukmajati, Mada. (2015). Politik Uang di Indonesia, Patronase dan Klientelisme pada Pemilu Legislatif 2014. Yogyakarta: PolGov UGM.

Borsuk, Richard \& Ching, Nancy. (2016). Liem Sioe Liong dan Salim Grup, Pilar Bisnis Soeharto. Jakarta: Kompas Gramedia.

Creswell, John W. (2010). Research Design, Pendekatan Kualitatif,
Kuantitatif dan Mixed. Yogyakarta:

Pustaka Pelajar.

Eisenstadt, S.N. and Roniger, L. (1984) Patrons, clients and friends: Interpersonal relations and the structure of trust in society, Cambridge University Press

Gaffar, Affan. (2004). Politik Indonesia, Transisi menuju Demokrasi. Yogyakarta: Pustaka Pelajar.

Geddes, Barbara. (1994). Politician's Dilemma, Building State Capacity in Latin America. Berkeley and Los Angeles, California, Universiy of California Press.

Geertz, Clifford. (1960). The Religion of Java. New York: The Free Press.

Hollyzon, Rahmat \& Sundari, Sri. (2015).

Pilkada, Penuh Euforia, Miskin Makna. Jakarta: Bestari

Kitschelt, H. and Wilkinson, S.I. (2007). Patrons, Clients, and Policies: Patterns of Democratic Accountability and Political Competition, Cambridge University Press.

Leeg, Keith R. (1983). Tuan Hamba dan Politisi. Jakarta: Sinar Harapan.

Mietzner, Marcus. (2011). Funding Pilkada: Illegal Campaign Financing in Indonesia's Local election. Dalam The State and Illegality in Indonesia. 
Diedit oleh Edward Aspinall dan Gerry van Klinken.Leiden: KITLV Press.

Mietzner, Marcus. (2013). Money,

Power, and Ideology. Political Parties

in Post Authoritarian Indonesia.

Singapura: National University of

Singapore Press.

Mikkelsen, Britha. (2001). Metode Penelitian Partisipatoris dan Upaya Pemberdayaan. Terjemahan Matheos Nalle. Jakarta: Yayasan Obor.

Miles, Mattew B; A.M, Huberman. (1992). Analisis Data Kualitatif. Jakarta: Universitas Indonesia Press.

Mujani, Syaiful; R. William Liddle dan K. Ambardi. (2012). Kuasa Rakyat: Analisis Tentang Perilaku Memilih dalam Pemilihan Legislatif dan Presiden Indonesia Pasca Orde Baru. Jakarta: Mizan.

Neuman, Lawrence. (2006). Social Research Methods. USA: University of Winconsin at Whitewater.

Nordholt, Henk Schulte \& van Klinken, Gerry. (2009). Politik Lokal di Indonesia. Jakarta: Yayasan Obor.

Patton, Michael Quinn. (2006). Metode Evaluasi Kualitatif. Terjemahan Budi Puspo Priyadi. Yogyakarta: Pustaka Pelajar.
Philipus, Ng \& Aini, Nurul. (2011). Sosiologi dan Politik. Jakarta: Raja Grafindo Persada.

Piattoni, Simona. (2001). Clientelism, Interests, and Democratic Representation: The European Experience in Historical and Comparative Perspective, Cambridge University Press.

Putnam, R. (1993). Making Democracy Work. Civic Traditions in Modern Italy. Princeton: Princeton University Press.

Rush, Michael; Althoff, Phillip. (2013). Pengantar Sosiologi Politik. Terjemahan Kartini Kartono. Jakarta: PT. Raja Grafindo Persada.

Scott, J. (1976). The moral economy of the peasant. New Haven: Yale University Press.

Scott, James C. (1972). Comparative Political Corruption, New Jersey, Prentice-Hall.

Tjenreng, MB. Zubakhrum. (2016). Pilkada Serentak, Penguatan Demokrasi di Indonesia. Jakarta: Pustaka Kemang.

Tomsa, Dirk. (2008). Party Politics and Democratization in Indonesia: Golkar in the Post - Soeharto Era. Routledge, London \& New York. 
Torsello, Davide. (2003). Trust, property and social change in a Southern Slovakian village. Munster: LIT.

Torsello, Davide. (2012). The New Environmentalism? Civil Society and Corruption in the Enlarged EU. Farham, UK: Ashgate. 